
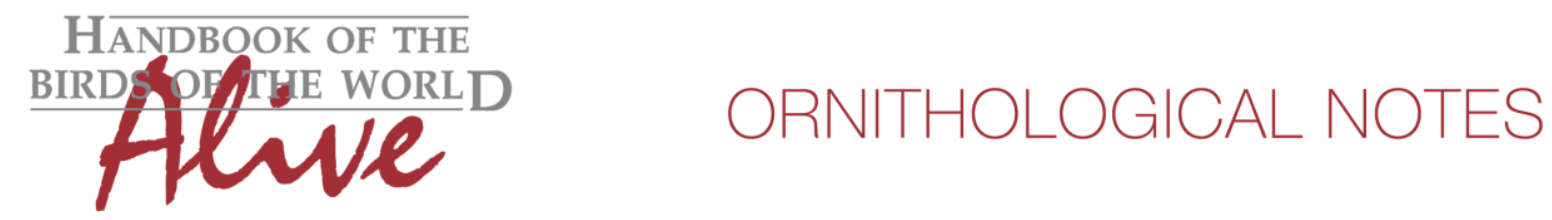

\title{
Notes on the vocalizations of White-crowned Manakin (Dixiphia pipra)
}

Peter Boesman

In the following we briefly analyze and compare voice of the different races of Whitecrowned Manakin (Dixiphia pipra). We also try to quantify the extent of any vocal differences using the criteria proposed by Tobias et al. (2010), as a support for taxonomic review. We have made use of sound recordings available on-line from Xeno Canto (XC) and Macaulay Library (ML).

This species has quite a few vocal groups, some very different from others. Given its present taxonomic arrangement as one single species, this may well be the only Manakin with such a divergent voice among races.

A qualitative analysis of 'song during lekking' by Andrew Spencer (2012), led to the following groups:

South/West Amazonian (ssp. discolor/pygmaea?/comata?/microlopha/separabilis)

Song is a long, buzzy, downslurred note given at fairly long intervals.

Range: E Ecuador, E Peru and southern Amazonian Brazil.

North Amazon/Guianan (ssp. pipra)

Song recalls the previous type in form, but is much higher pitched, more insect-like, and does not drop as much in pitch.

Range: North of the Amazon, and at least as far west as Mitu, Colombia and as far north as the Orinoco drainage and the Guianas.

Foothills North (ssp. coracina)

The song of this type consists of a short, evenly pitched buzzy note that ends in a short, slightly higher pitched and less buzzy 'hiccup'. The whole song is lower pitched than in the Amazon, and has a very different effect. It also seems to be given with shorter intervals.

Range: From Lara, Venezuela south along the Andean foothills through Ecuador to N Peru.

Coracina is also listed as being the subspecies in the Perija mountains in northern Colombia and western Venezuela (despite that population being disjunct from the other coracina populations and closer, geographically, to the central Colombian type).

Foothills South (ssp. occulta)

Song is a short, quiet buzz similar to, but higher pitched, than the first part of the coracina type, followed by a very short pause, and then a very high 'tink' note that is much louder than the buzz.

Range: Central and northern Peru in the foothills and lower subtropics. The range of this type goes from the north in southeastern-most Ecuador in the Cordillera del Condor, to the west in eastern La Libertad (see ML\#17461, 17454, 42071), and to the south it has been reported at least at the Cordillera Azul. Partially parapatric with coracina, which there occurs at lower elevations

Central Colombian (ssp. bolivari/unica)

No recordings of song available (a single available recording may simply be a call) 


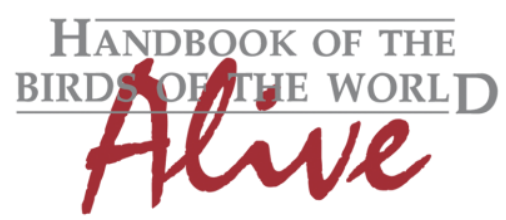

\section{ORNITHOLOGICAL NOTES}

\section{Choco (ssp. minima)}

Song is a long, upslurred buzzy call, nearly the opposite of the southern/western Amazonian type and very similar to the Central American type (see below).

Range: the southern Choco of Colombia

\section{Central American (ssp. anthracina)}

Song is similar to those in the Choco of Colombia, but with a more 'clipped' sound to the upslur.

Range: from Costa Rica to central Panama

\section{Southeast Brazil (ssp. cephaleucos)}

Song is a buzz similar to the southern/western Amazonian type, but it is a bit higher pitched, and the buzz has a slightly rougher quality. It also is a shorter vocalization that doesn't fall in pitch nearly as much (the change in pitch being barely perceptible in some examples), and occasionally has a lower pitched 'tonk' (mechanical?) sound at the end of the buzz.

Range: Atlantic SE Brazil
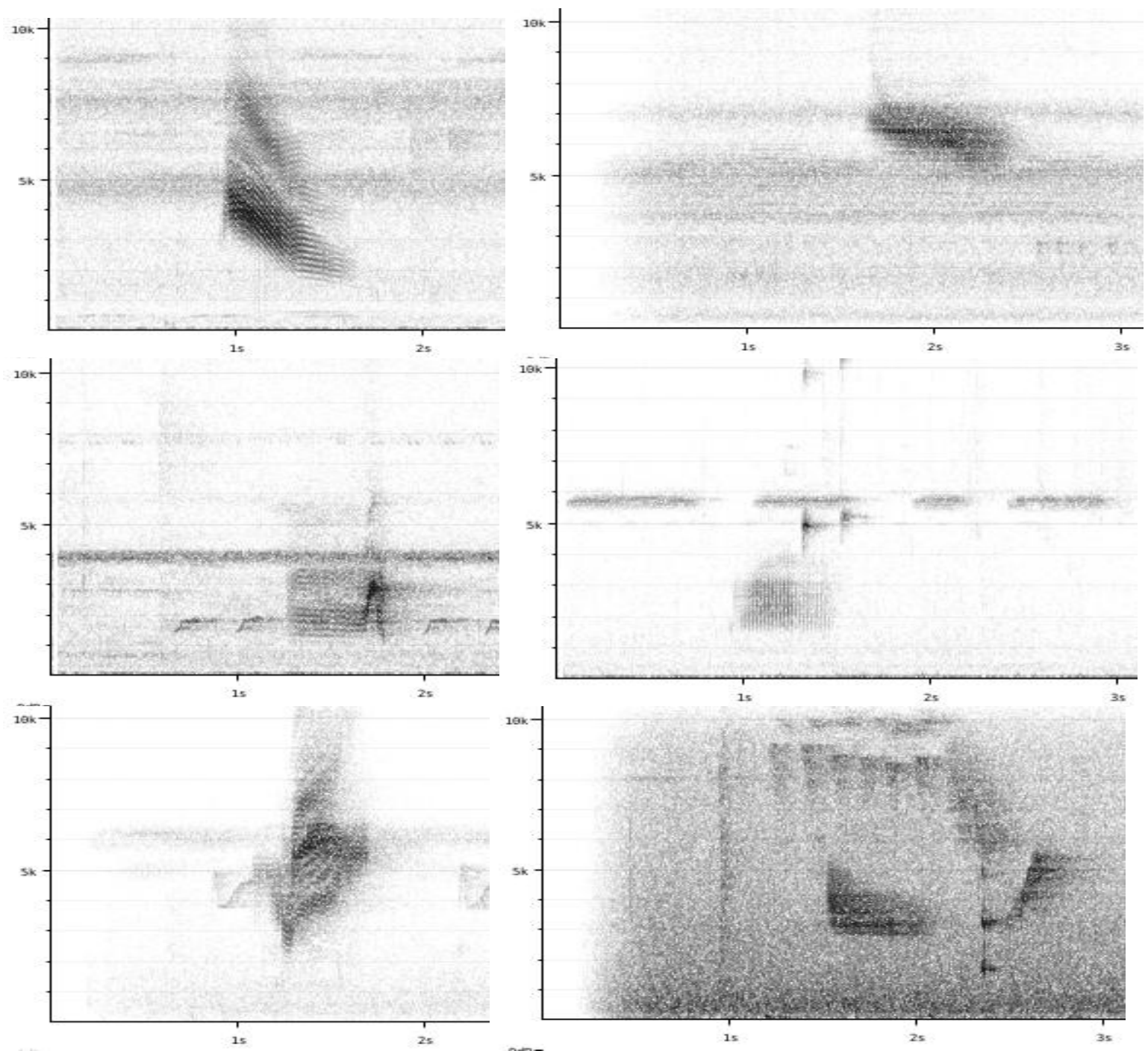

Figure 1: from top to bottom and left to right: Typical song of SW Amazonian, Guianan, Northern Foothills, Southern Foothills, Central American and SE Brazilian races. 

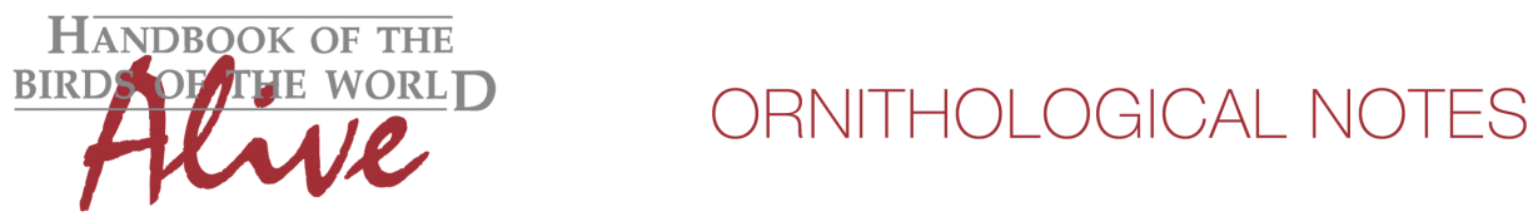

While these 7 groups (with a potential 8th one in Central Colombia) can probably be safely told apart in all cases (except for minima/anthracina) (Fig. 1), not all differ as much when measuring the basic sound parameters. Furthermore, measurements are far from straightforward due to the buzzy to noisy tone quality, resulting in fuzzy boundaries on a sonogram. The following are thus kind of average values.

South/West Amazonian (ssp. discolor/pygmaea?/comata?/microlopha/separabilis)

$\begin{array}{ll}\text { \# of notes } & 1 \text { or } 2 \\ \text { total length } & 0.6 \mathrm{~s} \text { (or } 0.8 \mathrm{~s} \text { when 2nd note included) } \\ \text { max. freq. } & 4000-5000 \mathrm{~Hz} \\ \text { min. freq. } & 1400-1900 \mathrm{~Hz} \\ \text { freq. range } & 3000-4000 \mathrm{~Hz} \\ \text { start freq. - end freq. } & 1600-1700 \mathrm{~Hz}\end{array}$

$\begin{array}{ll}\text { North Amazon/Guianan (ssp. pipra) } \\ \text { \# of notes } & 1 \\ \text { total length } & 1.0-1.04 \mathrm{~s} \\ \text { max. freq. } & 7500-8700 \mathrm{~Hz} \\ \text { min. freq. } & 3900-4500 \mathrm{~Hz} \\ \text { freq. range } & 3000-4500 \mathrm{~Hz} \\ \text { start freq. - end freq. } & 1000-1500 \mathrm{~Hz}\end{array}$

Foothills North (ssp. coracina)

$\begin{array}{ll}\text { \# of notes } & 2 \text { (or up to } 26 \text { when well articulated buzzy call) } \\ \text { total length } & 0.6 \mathrm{~s} \text { (occasionally up to 1.5s) } \\ \text { max. freq. } & 2500-2800 \mathrm{~Hz} \\ \text { min. freq. } & 1000-1100 \mathrm{~Hz} \\ \text { freq. range } & 1500 \mathrm{~Hz} \\ \text { start freq. - end freq. } & 700 \mathrm{~Hz}\end{array}$

Foothills South (ssp. occulta)

$\begin{array}{ll}\text { \# of notes } & 15-20 \text { (buzzy call is very well articulated) } \\ \text { total length } & 0.38-0.5 \mathrm{~s} \\ \text { max. freq. } & 4600-4700 \mathrm{~Hz} \\ \text { min. freq. } & 1400 \mathrm{~Hz} \\ \text { freq. range } & 3400-3500 \mathrm{~Hz} \\ \text { start freq. - end freq. } & -1300 \text { to }-1800 \mathrm{~Hz}\end{array}$

Choco (ssp. minima) and Central American (ssp. anthracina)

$\begin{array}{ll}\text { \# of notes } & 1 \text { (or 2?) } \\ \text { total length } & 0.48-0.7 \mathrm{~s} \\ \text { max. freq. } & 5700-7000 \mathrm{~Hz} \\ \text { min. freq. } & 1670-2500 \mathrm{~Hz} \\ \text { freq. range } & 4000-6000 \mathrm{~Hz} \\ \text { start freq. - end freq. } & -3000 \text { to }-3800 \mathrm{~Hz}\end{array}$

Southeast Brazil (ssp. cephaleucos)

$\begin{array}{ll}\text { \# of notes } & 2 \\ \text { total length } & 0.58-0.60 \mathrm{noisy} \text { note }(0.74-0.76 \text { including 2nd note) } \\ \text { max. freq. } & 4200-5100 \mathrm{~Hz} \\ \text { min. freq. } & 1400-1580 \mathrm{~Hz} \\ \text { freq. range } & 2800-3600 \mathrm{~Hz} \\ \text { start freq. - end freq. } & 0 \text { (of buzzy note) }\end{array}$



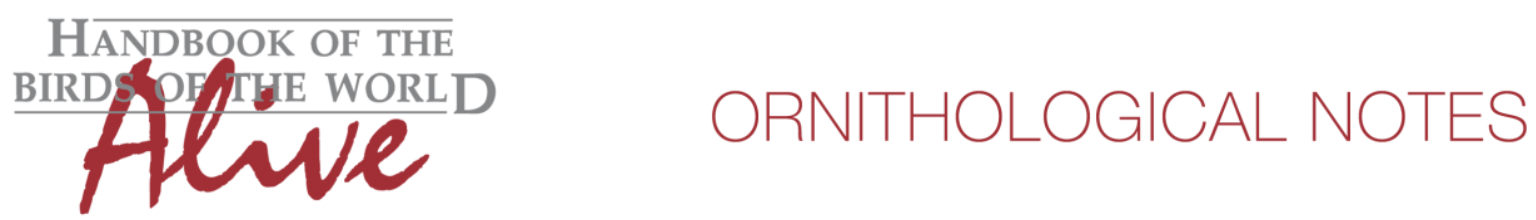

The above 6 groups are perfectably identifiable, but few have basic sound parameters which are unique. Nevertheless, we can differentiate based on the following quantifiable parameters:

North Amazon/Guianan (ssp. pipra) stands out most because of by far the highest max. and min. frequencies (score 3) and the longest drawn-out buzzy note (score 2-3) -> total score 5-6

Foothills $\mathbf{N}$ (ssp. coracina) stands out because it has the lowest max. and min. frequency (score 2-3) and the lowest frequency range (score 2) -> total score 4-5

Foothills S (ssp. occulta) stands out because it is the only one where the 'buzzy note' is so well articulated that it has changed into a rattle with countable notes (score 2 ) and a very short total length(score 1 ) -> total score 3

Choco (ssp. minima) and Central American (ssp. anthracina) stand out because they have the largest frequency range (score 2 ) and the largest rise in frequency from start to end (score 1 ) $->$ total score $2-3$

Southeast Brazil (ssp. cephaleucos) stands out because it has always 2 notes (difference with e.g. S Amazonia) and has a buzzy note at a constant frequency $->$ total score 2

South/West Amazonian (ssp. discolor/pygmaea?/comata?/microlopha/separabilis) remains with differences vs. all races explained above.

This note was finalized on 23rd June 2015, using sound recordings available on-line at that moment. We would like to thank in particular the many sound recordists who placed their recordings for this species on XC and $\mathrm{ML}$.

\section{References}

Spencer, A. (2012). White-crowned Manakin vocal variation. URL: http://www.xenocanto.org/article/108 (download April 2015).

Tobias, J.A., Seddon, N., Spottiswoode, C.N., Pilgrim, J.D., Fishpool, L.D.C. \& Collar, N.J. (2010). Quantitative criteria for species delimitation. Ibis 152(4): 724-746.

\section{Recommended citation}

Boesman, P. (2016). Notes on the vocalizations of White-crowned Manakin (Dixiphia pipra). HBW Alive Ornithological Note 107. In: Handbook of the Birds of the World Alive. Lynx Edicions, Barcelona. (retrieved from http://www.hbw.com/node/932012 on 2 August 2016). 